\begin{tabular}{|c|c|}
\hline $\begin{array}{c}\text { European Association for the } \\
\text { Development of Renewable Energies, Environment } \\
\text { and Power Quality (EA4EPQ) }\end{array}$ & $\begin{array}{c}\text { International Conference on Renewable Energies and Power Quality } \\
\text { (ICREPQ'12) }\end{array}$ \\
Santiago de Compostela (Spain), 28th to 30th March, 2012
\end{tabular}

\title{
The Effect on Emissions of using Alternative Fuels in Turbo-Charged Diesel Engines
}

\author{
S.Hudson ${ }^{1}$, C.Stubbs ${ }^{1}$ and W.Weston ${ }^{1}$ \\ ${ }^{1}$ Department of Engineering and Technology \\ School of Computing and Engineering \\ University of Huddersfield \\ Huddersfield HD1 3DH, UK \\ Mobile: +447778408572, Email: w.weston@hud.ac.uk
}

\begin{abstract}
The paper outlines the Emission and Biofuel Directives relating to $\mathrm{CO}_{2}$ emissions in cars and the fiscal penalties incurred by manufacturers failing to meet targets.

The effect on emissions of the biofuel directives are quantified through a test programme which measures emissions from a turbo-charged diesel engine using a range of biodiesel fuels, using standard diesel fuel to obtain a comparison. The tests measure $\mathrm{O}_{2}, \mathrm{NO}_{\mathrm{x}}$, THC and $\mathrm{CO}$ emissions data as well as $\mathrm{CO}_{2}$. The results are difficult to quantify but, with the exception of corn oil show an increase in $\mathrm{CO}_{2}$ emissions. Corn oil also shows a reduction in other emissions.

The discussion considers other mechanisms which can reduce overall global automotive emissions including range extenders for electric vehicles.
\end{abstract}

\section{Key words}

Turbo-charged diesel engines, Emissions, Bio fuels, Range extenders.

\section{Introduction}

\subsection{Background}

The reduction of diesel engine emissions used in modern transportation systems is of considerable interest throughout the developed world as green issues begin to predominate. Historically, G8 governments in Montreal, 1987 developed a joint policy on the ozone layer and subsequently, further summits relating to climate change were scheduled with the United Nations Framework Convention on Climate Change (UNFCCC). More commonly known as the Kyoto Protocol, it made significant proposals relating to the reduction of four Greenhouse Gases and two gas types. The most noteworthy of these, particularly for the transport industry is the reduction in Carbon Dioxide [1]. The legislation adopted by the EU in relation to Carbon
Dioxide cuts for passenger vehicles is of particular significance as this is the legislation that has been created in order for EU countries to meet their obligations to the UNFCCC. In addition to this gas, Nitrous Oxide emissions must also be reduced in accordance with the UNFCCC [2].

NOx emissions have a much larger presence in the exhaust gases of diesel fuels so this investigation will focus on the variation in diesel engine exhaust gases of noxious and harmful constituents using both conventional diesel fuels and biodiesel fuels.

A variety of ways have been developed in an effort to reduce society's reliance on fossil fuels. Recently there has been a shift towards increased utilisation of electric vehicles with some mainstream manufacturers now developing and producing commercially available EVs. However the problem of clean production plus transmission losses when using electricity as a primary source remains. Recent developments of electric vehicle 'range extenders' appear more practical.

Other suggestions have centred on using vehicles less and finding alternative means of transport. However, for this report, the focus will be on the use of biofuels. Simply, these are fuels that have percentage of a biological component which on the whole, can be used in internal combustion engines with little or no modification.

\subsection{Emission directives}

There have been a number of EU directives over the years relating to the $\mathrm{CO}_{2}$ emissions of cars, the most recent and important one of these is (EC) No. 443/2009, bought into law $23^{\text {rd }}$ April 2009.

The key points of this legislation are based around the fleet average $\mathrm{CO}_{2}$ emissions for new cars registered in the European Union. The ultimate aim for this legislation is the fleet wide reduction of $\mathrm{CO}_{2}$ emissions output to $130 \mathrm{~g} / \mathrm{km}$ by 2015 , this target is split into stages which are 
given below:

- $2012,65 \%$ of newly registered cars at or below the $130 \mathrm{~g} / \mathrm{km}$ target

- $2013,75 \%$ of newly registered cars at or below the $130 \mathrm{~g} / \mathrm{km}$ target

- $2014,80 \%$ of newly registered cars at or below the $130 \mathrm{~g} / \mathrm{km}$ target

- $2015,100 \%$ of the newly registered cars meet the $130 \mathrm{~g} / \mathrm{km}$ target

In order to provide incentive to the manufacturers there are fiscal penalties relating to non compliance with the directives. Although the penalties appear to be relatively small they are applied to each car sold by the manufacturer. Simplified, from 2012 through to 2018 the following penalties are applied:

- For the first $\mathrm{g} / \mathrm{km}$ over the target a $€ 5$ per car registered penalty is applied

- For the second $\mathrm{g} / \mathrm{km}$ over the target a $€ 15$ per car registered penalty is applied

- For the third $\mathrm{g} / \mathrm{km}$ over the target a $€ 25$ per car registered penalty is applied

- $\quad$ For each subsequent $\mathrm{g} / \mathrm{km}$ over the target a $€ 95$ per car registered penalty is applied

Further to these penalties, after 2018 there will be a $€ 95$ penalty commencing with the first $\mathrm{g} / \mathrm{km}$ over the target emissions. (Extracted from www.eur-lex.europa.eu)

The long term target set out by this directive is to reduce fleet average emissions to $95 \mathrm{~g} / \mathrm{km}$ by the year 2020 .

\subsection{Biofuel directives}

In addition to the $\mathrm{CO}_{2}$ emission regulations there are two key EU directives relating to the use of biofuels.

The first of these is Renewable Transport Fuels Obligation Amendment April 2009 (RTFO) and the second is Renewable Energy Directive/Fuel Quality Directive 2009 (RED) [3].

The RTFO is aimed at the suppliers of fossil fuels and is centred on the inclusion of renewable fuels as part of each manufacturer/suppliers fuel sales in the EU. The inclusion of biofuels has a dual effect, firstly it will reduce the $\mathrm{CO}_{2}$ emissions of the fuel that is being supplied for vehicles and secondly there will be a reduction in fossil fuel usage Europe wide. The yearly targets for renewable fuel usage for this directive are:

- 2008: $2.5641 \%$ of fuel sold by supplier

- 2009: 3.3592\%

- 2010:3.6269\%

- 2011:4.1667\%

- 2012: $4.7120 \%$

- Subsequent years: The renewable fuel usage must be equivalent to $5.2632 \%$ of fuel sold by supplier.

Most of the fuel companies have decided to tackle this renewable fuel component by producing their fuels as a blend. For instance in Shell V power diesel fuel there is a component of biodiesel that is produced from waste natural gas, by blending this bio diesel they are coming towards the equivalent percentage target without actually producing a $100 \%$ renewable fuel. In the same way, in Sweden in particular where there is widespread usage of E85 blend Ethanol this production will count towards the targets. This seems to be particularly successful especially when it is considered that approximately $15 \%$ of that fuel is made from a renewable component and will therefore contribute a significant amount to the target.

The RED has a large bearing on renewable fuel usage across Europe. It sets out a Europe wide target and then further breaks this down in to individual member countries targets, based largely around total emissions, current usage of renewable fuels and infrastructure to manufacture and supply renewable fuels. The key points are:

- $20 \%$ of energy production across the EU is to be drawn from renewable sources by 2020

- $15 \%$ of the energy production in the UK is to be drawn from renewable sources by 2020

- $10 \%$ of energy used in the transportation sector is to be made from renewable sources by 2020

- There must be a minimum reduction in green house gases from road transport of $6 \%$ by 2020

Each member country was obliged to submit a plan showing how they intended to reach these targets that was then ratified by the European Commission. It is interesting to note the 2005 use of renewable energy (on which the initial documentation is based) compared to the targets, for the UK it was $1.3 \%$ renewable sourced energy in 2005 compared with the target of $15 \%$ by 2020 . Compare this to Sweden where in $2005,39.8 \%$ of energy was from renewable sources with a target of $49 \%$ by 2020. This also shows there is recognition for countries that have already begun the process of green house gas reduction through renewable energy with smaller percentage targets.

\section{Objectives}

The objectives of this investigation are to enable a comparison of the emissions from a variety of biofuels against a benchmark of a commercially available standard [4]. This will be achieved by:

- Establishing a test cell set up suitable for comprehensive engine and emissions testing.

- Selecting a test engine that complies with EU stage 3 emission regulations, thus ensuring objectivity of the results.

- Defining the production method of the bio diesel fuels to be tested, again ensuring the objectivity of the results.

- Selecting a range of bio diesel fuels for the emission comparisons, namely vegetable oil, sunflower oil and corn oil.

- Developing a test schedule that will enable a useful and effective comparison of the emissions from each fuel.

- Obtaining emission results for each bio fuel and undertaking a comparison against the benchmark standard diesel fuel.

\section{Experimental Investigation}

\subsection{Test Arrangements}

The two methods used to test powertrains are:

3.1.1 Chassis dynamometer arrangement.

Here an entire vehicle is used either with the wheels on absorbing rollers or with the axles attached to absorption 
dynamometers. Testing in this way is usually carried out by aftermarket tuners or by manufacturers during benchmarking tests. The figures obtained by chassis dynamometers are for wheel horsepower and wheel torque values. These figures take into account all the driveline losses and are naturally lower than those derived solely from engine test work. It is in this way that the European emissions tests are performed. This allows the manufacturers to make use of supplementary systems that they may have fitted to their cars such as start stop technologies.

3.1.2 Engine test cell arrangement [5].

Here the engine (with or without gearbox) is connected directly to a dynamometer via a prop shaft. The engine can then either be controlled by the throttle and the dynamometer used for absorption purposes or the dynamometer can be used to 'motor' the engine.

This investigation employed a test cell with a $200 \mathrm{~kW}$ AC Dynamometer. It is a 4 quadrant regenerative drive and can both motor and absorb the connected engine. It has a 1024ppr optical encoder to allow high precision control of the dynamometer and engine. The dynamometer can be used to control a maximum torque of $478 \mathrm{Nm}$ between 10 and 4000rpm and can also control its maximum rated power of $200 \mathrm{~kW}$ from 4000 through to $8000 \mathrm{rpm}$. Its fuel delivery system has been upgraded for use with bio fuels. The cell is equipped with a Horiba EXSA-1500L exhaust gas analyser. A heated line runs from a takeoff in the exhaust system through to the analyser where the gas can be split into the component gases with the display then showing, AFR, $\mathrm{CO}_{2}, \mathrm{O}_{2}, \mathrm{NOx}, \mathrm{THC}, \mathrm{CO}$ and Lambda values. These values give an indication of the cleanliness of the exhaust gas as well as showing the individual emissions. Figure 2.1 shows a typical screen display.

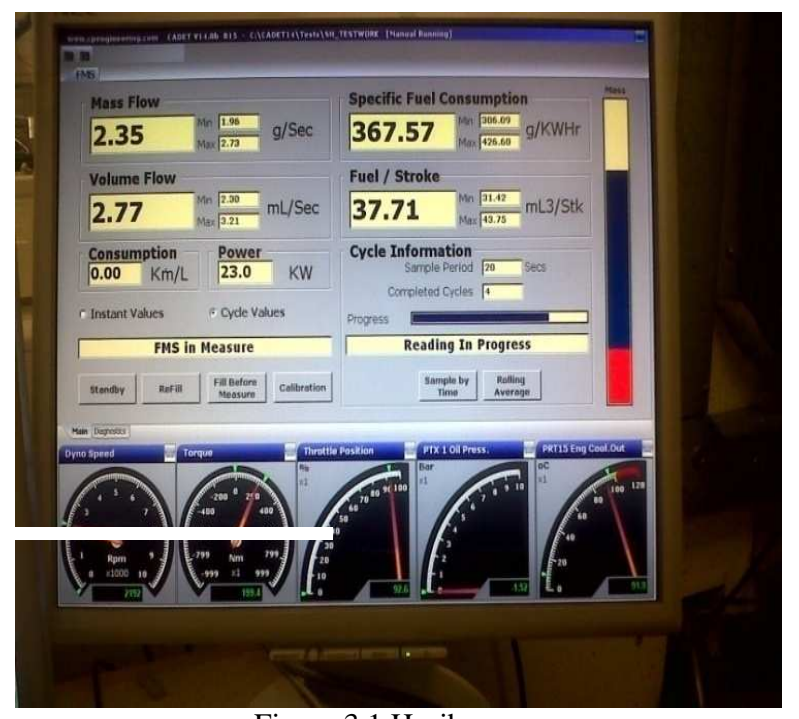

Figure 3.1 Horiba screen

\subsection{Test Engine}

The engine to be used for the test work is the JCB Dieselmax 444TCA IPU, a 4.4litre straight four turbocharged engine. They are normally employed in construction vehicles and marine applications

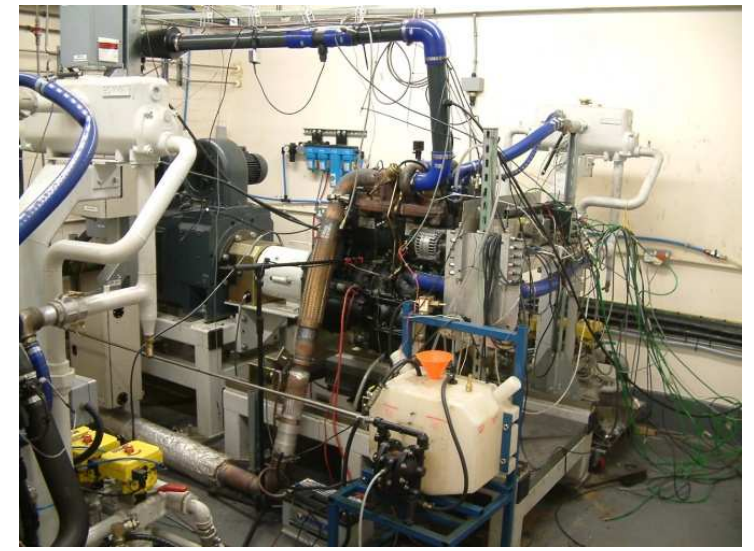

Figure 3.2 Engine \& Dynamometer

The engine in use at the university is modified to run with an aftermarket turbocharger with a fixed wastegate. This provides the engine with maximum boost pressure at all running conditions as well as guaranteeing that the engine can run at required torque settings throughout the speed range.

The JCB Dieselmax used complies with the EU Stage 3A Emissions Regulations. These are the regulations relating to the emissions from 'Non road mobile vehicles'. Stage 3A came into force in January 2006 and was superseded by Stage 3B from January 2011, for which JCB produce the ECOMax engine family.

\subsection{Production of Biofuels}

The university has a Fuelpod ${ }^{\circledR} 2$ system manufactured by green fuels. This is a commercially available setup that is capable of producing 50 litre batches of biodiesel. The system not only allows the reaction to split the fatty acids and glycerol, but is then able to purify the resultant crude biodiesel into a refined final product. This diesel can then be used in a vehicle or, in this case, the test engine. 50 litres of each of the following fuels were manufactured for the tests: Vegetable oil, Sunflower oil and Corn oil, enough fuel being produced to enable a comparison between the benchmark commercial diesel, a $50 \%$ mixture of diesel and biodiesel and $100 \%$ biodiesel.

\subsection{Test procedure}

Performance and emission recordings were undertaken for torque settings of $100 \mathrm{Nm}, 200 \mathrm{Nm}$ and $300 \mathrm{Nm}$ for a range of speeds between 1000 and $3000 \mathrm{rev} / \mathrm{min}$ for each of the fuels tested. Diesel fuel was used as a standard to compare performance and emissions from a selection of biofuels, namely vegetable oil, sunflower oil and corn oil. Performance measurements comprised shp, torque and specific fuel consumption whilst emission measurements comprised $\mathrm{CO}_{2}, \mathrm{O}_{2}, \mathrm{NO}_{\mathrm{x}} \mathrm{THC}$ and $\mathrm{CO}$, yielding six sets of results for each fuel tested, a total of 24 result sets. This paper is concerned only with emissions and so, for practical reasons, only a selection of the emission recording are presented in this paper. 


\section{Results}

A selection of emission plots are presented for comparison and discussion, together with tables which yield a comparison with the benchmark diesel fuel.

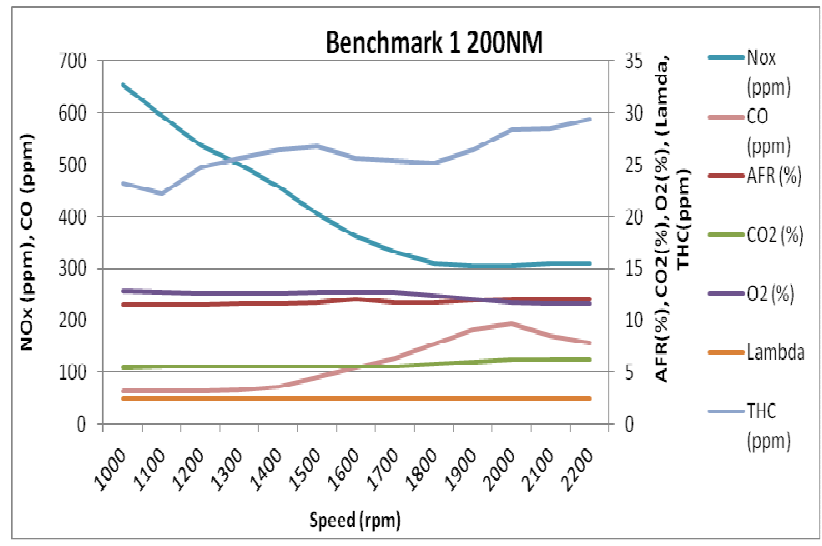

Figure 4.1 Diesel fuel emissions

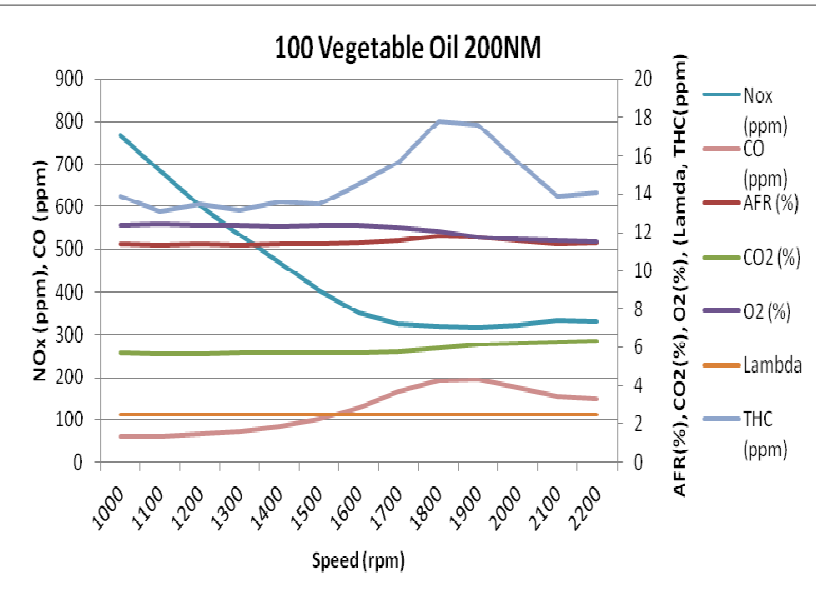

Figure 4.3 Vegetable oil emissions
Figures 4.1 to 4.4 present graphical results for the benchmark diesel fuel and vegetable oil, sunflower oil and corn oil respectively.

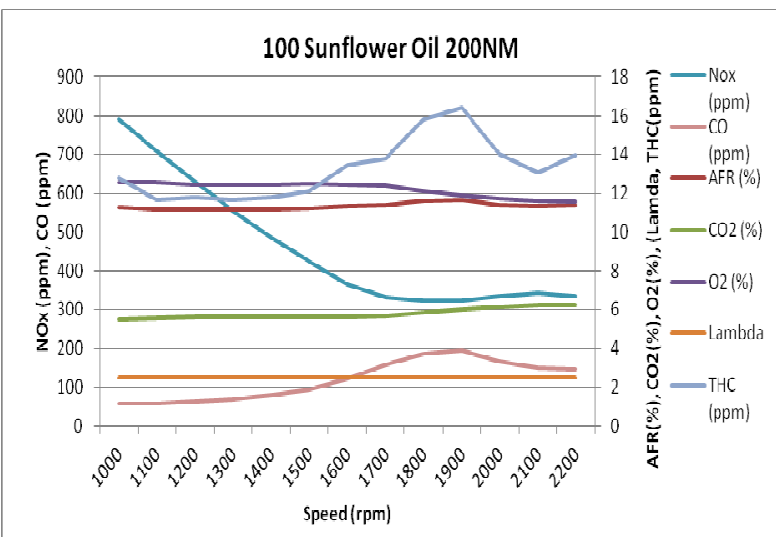

Figure 4.2 Sunflower oil emissions

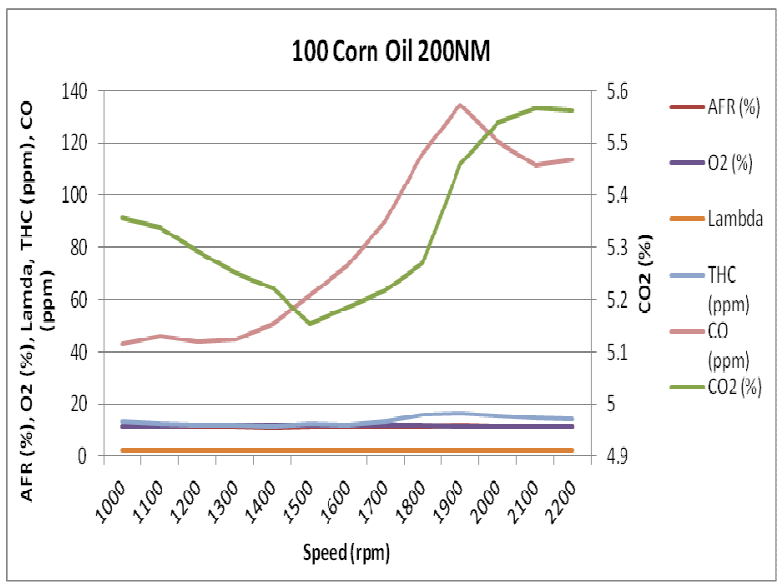

Figure 4.4 Corn oil emissions

Tables 4.1 to 4.3 present the associated comparison of emissions data for the standard and bio fuels examined

Table 4.1: Emissions data comparison for Diesel Oil and Vegetable Oil

\begin{tabular}{|c|c|c|c|c|c|c|c|c|c|c|c|c|c|c|c|}
\hline \multirow{2}{*}{$\begin{array}{l}\text { Speed } \\
(\mathrm{rpm})\end{array}$} & \multicolumn{2}{|c|}{$\mathrm{CO} 2(\%)$} & \multirow[t]{2}{*}{$\begin{array}{c}\% \\
\text { diff }\end{array}$} & \multicolumn{2}{|c|}{$\mathrm{O} 2(\%)$} & \multirow[t]{2}{*}{$\begin{array}{c}\% \\
\text { diff }\end{array}$} & \multicolumn{2}{|c|}{ NOx (ppm) } & \multirow[t]{2}{*}{$\begin{array}{c}\% \\
\text { diff }\end{array}$} & \multicolumn{2}{|c|}{ THC (ppm) } & \multirow[t]{2}{*}{$\begin{array}{l}\% \\
\text { diff }\end{array}$} & \multicolumn{2}{|c|}{$\mathrm{CO}(\mathrm{ppm})$} & \multirow[t]{2}{*}{$\begin{array}{c}\% \\
\text { diff }\end{array}$} \\
\hline & Diesel & $\begin{array}{c}100 \% \\
\text { Veg }\end{array}$ & & Diesel & $\begin{array}{c}100 \% \\
\text { Veg }\end{array}$ & & Diesel & $\begin{array}{c}100 \% \\
\text { Veg }\end{array}$ & & Diesel & $\begin{array}{c}100 \% \\
\text { Veg }\end{array}$ & & Diesel & $\begin{array}{c}100 \% \\
\text { Veg }\end{array}$ & \\
\hline 1100 & 0.04 & 5.64 & -1.90 & 12.70 & 12.42 & 2.22 & 611 & 656 & -12.27 & 20.92 & 13.08 & 37.46 & 60.33 & 62.66 & -3.86 \\
\hline 1200 & 5.58 & 5.66 & -1.39 & 12.64 & 12.38 & 2.05 & 566 & 604 & -6.76 & 21.42 & 13.47 & 37.13 & 60.76 & 67.92 & -11.78 \\
\hline 1500 & 5.55 & 5.70 & -2.77 & 12.69 & 12.37 & 2.54 & 421 & 403 & 4.23 & 24.46 & 13.48 & 44.88 & 87.14 & 101.89 & -16.92 \\
\hline 1600 & 1 & 5.68 & -3.10 & 12.74 & 12.37 & 2.89 & 373 & 351 & 5.89 & 24.67 & 14.50 & 41.24 & 104.72 & 129.87 & -24.02 \\
\hline 1700 & 5.57 & 5.78 & -3.76 & 12.72 & 12.27 & 3.53 & 338 & 326 & 3.55 & 24.17 & 15.64 & 35.30 & 122.54 & 165.76 & -35.27 \\
\hline 1800 & 5.79 & 5.95 & -2.79 & 12.39 & 12.04 & 2.85 & 313 & 318 & -1.62 & 24.10 & 17.82 & 26.06 & 143.69 & 192.76 & -34.15 \\
\hline
\end{tabular}


Table 4.2 Emissions data comparison for Diesel fuel and Sunflower Oil

\begin{tabular}{|c|c|c|c|c|c|c|c|c|c|c|c|c|c|c|c|}
\hline Speed & \multicolumn{2}{|c|}{$\mathrm{CO} 2(\%)$} & \multirow[t]{2}{*}{$\%$ diff } & \multicolumn{2}{|c|}{$\mathrm{O} 2(\%)$} & \multirow[t]{2}{*}{$\%$ diff } & \multicolumn{2}{|c|}{ NOx (ppm) } & \multirow[t]{2}{*}{$\%$ diff } & \multicolumn{2}{|c|}{ THC (ppm) } & \multicolumn{2}{|c|}{$\%$ diff } & $\mathrm{CO}(\mathrm{ppm})$ & \multirow[t]{2}{*}{$\% \operatorname{dif}$} \\
\hline$(\mathrm{rpm})$ & Diesel & $\begin{array}{c}100 \% \\
\text { Sun }\end{array}$ & & Diesel & $\begin{array}{c}100 \% \\
\text { Sun } \\
\end{array}$ & & Diesel & $\begin{array}{c}100 \% \\
\text { Sun } \\
\end{array}$ & & Diesel & $\begin{array}{l}100 \% \\
\text { Sun }\end{array}$ & & Diesel & $\begin{array}{c}100 \% \\
\text { Sun } \\
\end{array}$ & \\
\hline 1000 & 5.46 & 5.53 & -1.15 & 12.54 & 12.57 & -0.21 & 661 & 789 & -19.44 & 20.57 & 12.80 & 37.76 & 64.86 & 58.43 & 9.91 \\
\hline 1100 & 5.52 & 5.56 & -0.72 & 12.41 & 12.54 & -1.10 & 597 & 708 & -18.53 & 20.13 & 11.68 & 41.99 & 63.88 & 57.13 & 10.57 \\
\hline 1200 & 5.56 & 5.61 & -0.90 & 12.40 & 12.46 & -0.50 & 531 & 632 & -18.98 & 22.04 & 11.79 & 46.52 & 65.91 & 62.43 & 5.27 \\
\hline 1300 & 5.58 & 5.63 & -0.75 & 12.31 & 12.47 & -1.36 & 504 & 556 & -10.27 & 22.17 & 11.66 & 47.39 & 65.59 & 68.43 & -4.33 \\
\hline 1400 & 5.58 & 5.63 & -0.81 & 12.31 & 12.45 & -1.11 & 447 & 484 & -8.48 & 22.21 & 11.76 & 47.05 & 73.42 & 79.22 & -7.89 \\
\hline 1500 & 5.56 & 5.62 & -1.03 & 12.34 & 12.49 & -1.24 & 393 & 423 & -7.62 & 22.58 & 12.14 & 46.22 & 94.26 & 95.00 & -0.79 \\
\hline 1600 & 5.54 & 5.62 & -1.38 & 12.39 & 12.44 & -0.45 & 349 & 364 & -4.23 & 23.22 & 13.47 & 41.97 & 113.82 & 121.84 & -7.05 \\
\hline 1700 & 5.63 & 5.70 & -1.18 & 12.29 & 12.39 & -0.83 & 321 & 331. & -3.25 & 23.21 & 13.82 & 40.47 & 133.27 & 157.56 & -18.23 \\
\hline 1800 & 5.87 & 5.85 & 0.27 & 11.91 & 12.14 & -1.97 & 303 & 323 & -6.38 & 23.11 & 15.82 & 31.56 & 161.85 & 184.88 & -14.23 \\
\hline 1900 & 6.08 & 6.03 & 0.73 & 11.64 & 11.88 & -2.12 & 300 & 322 & -7.48 & 24.28 & 16.41 & 32.42 & 185.52 & 193.23 & -4.16 \\
\hline 2000 & 6.26 & 6.14 & 1.95 & 11.35 & 11.75 & -3.57 & 298 & 334 & -12.08 & 26.41 & 13.99 & 47.01 & 196.08 & 166.31 & 15.18 \\
\hline 2100 & 6.31 & 6.22 & 1.48 & 11.32 & 11.62 & -2.69 & 304 & 342 & -12.66 & 26.64 & 13.06 & 50.97 & 167.87 & 149.88 & 10.71 \\
\hline 2200 & 6.31 & 6.25 & 1.00 & 11.31 & 11.57 & -2.32 & 306 & 356 & -9.83 & 27.10 & 13.94 & 48.54 & 155.14 & 145.92 & 5.94 \\
\hline
\end{tabular}

Table 4.3: Emissions data comparison for Diesel fuel and Corn oil

\begin{tabular}{|c|c|c|c|c|c|c|c|c|c|c|c|c|}
\hline Speed & \multicolumn{2}{|c|}{$\mathrm{CO} 2(\%)$} & $\begin{array}{c}\% \\
\text { diff }\end{array}$ & \multicolumn{2}{|c|}{$\mathrm{O} 2(\%)$} & \multirow[t]{2}{*}{$\begin{array}{c}\% \\
\text { diff }\end{array}$} & \multicolumn{2}{|c|}{ THC (ppm) } & \multirow[t]{2}{*}{$\begin{array}{c}\% \\
\text { diff } \\
\end{array}$} & \multicolumn{2}{|c|}{$\mathrm{CO}(\mathrm{ppm})$} & \multirow[t]{2}{*}{$\begin{array}{c}\% \\
\text { diff } \\
\end{array}$} \\
\hline (rpm) & Diesel & $\begin{array}{l}100 \% \\
\text { Corn }\end{array}$ & & Diesel & $\begin{array}{l}100 \% \\
\text { Corn }\end{array}$ & & Diesel & $\begin{array}{l}100 \% \\
\text { Corn }\end{array}$ & & Diesel & $\begin{array}{l}100 \% \\
\text { Corn }\end{array}$ & \\
\hline 1000 & 5.63 & 5.36 & 4.93 & 12.96 & 11.51 & 11.20 & 21.78 & 13.45 & 38.23 & 56.01 & 43.10 & 23.05 \\
\hline 1100 & 5.62 & 5.34 & 4.97 & 12.99 & 11.52 & 11.30 & 21.71 & 12.27 & 43.47 & 56.77 & 45.91 & 19.13 \\
\hline 1200 & 5.59 & 5.29 & 5.39 & 13.03 & 11.63 & 10.72 & 20.80 & 11.78 & 43.39 & 55.61 & 43.72 & 21.38 \\
\hline 1300 & 5.54 & 5.25 & 5.12 & 13.11 & 11.67 & 10.97 & 21.45 & 11.78 & 45.09 & 55.61 & 44.71 & 19.60 \\
\hline 1400 & 5.48 & 5.22 & 4.66 & 13.19 & 11.74 & 10.99 & 24.58 & 11.46 & 53.37 & 63.99 & 50.60 & 20.93 \\
\hline 1500 & 5.45 & 5.15 & 5.51 & 13.22 & 11.78 & 10.85 & 26.34 & 12.45 & 52.73 & 80.03 & 61.86 & 22.71 \\
\hline 1600 & 5.45 & 5.18 & 4.92 & 13.26 & 11.82 & 10.83 & 26.12 & 12.08 & 53.75 & 95.62 & 73.26 & 23.38 \\
\hline 1700 & 5.52 & 5.22 & 5.46 & 13.18 & 11.82 & 10.34 & 25.13 & 13.04 & 48.10 & 111.81 & 90.08 & 19.44 \\
\hline 1800 & 5.64 & 5.27 & 6.54 & 13.01 & 11.74 & 9.76 & 25.10 & 15.90 & 36.65 & 125.53 & 115.74 & 7.80 \\
\hline 1900 & 5.86 & 5.46 & 6.84 & 12.68 & 11.52 & 9.14 & 26.27 & 16.62 & 36.75 & 139.80 & 134.57 & 3.74 \\
\hline 2000 & 5.98 & 5.54 & 7.36 & 12.57 & 11.44 & 9.01 & 23.99 & 15.63 & 34.87 & 140.00 & 120.74 & 13.76 \\
\hline 2100 & 5.99 & 5.57 & 7.02 & 12.57 & 11.42 & 9.15 & 23.64 & 14.40 & 39.09 & 128.61 & 111.33 & 13.44 \\
\hline 2200 & 5.88 & 5.56 & 5.34 & 12.73 & 11.44 & 10.12 & 22.61 & 14.16 & 37.36 & 126.82 & 113.82 & 10.25 \\
\hline
\end{tabular}

\section{Discussion}

\subsection{Results}

The measured emissions data is best described qualitatively since no discernible trend can be observed. Throughout the range of biofuels tested, carbon dioxide $\left(\mathrm{CO}_{2}\right)$ emissions are slightly worse, at up to $5 \%$, than the benchmark diesel fuel. Oxygen content $\left(\mathrm{O}_{2}\right)$, which is of course not harmful, has nominally decreased $4 \%$ for vegetable and sunflower oil whilst corn oil yields a much decreased value of $12 \%$. This is accepted as indicating more effective combustion. Nitrous oxide $\left(\mathrm{NO}_{\mathrm{x}}\right)$ measurements were consistently worse for vegetable and sunflower oil with up to $20 \%$ more emissions recorded. The Nitrous oxide $\left(\mathrm{NO}_{\mathrm{x}}\right)$ measurements for corn oil were not successful, a failure conveniently attributed to software problems in the measurement system. There was a reduction in the total unburned hydrocarbon content (THC) consistently across the range with corn oil achieving a 54\% reduction. Carbon monoxide measurements varied with vegetable oil recording an increase up to $35 \%$, sunflower oil varying from an $8 \%$ increase to an $11 \%$ decrease whilst corn oil emitted up to $23 \%$ more $\mathrm{CO}$. 
The author considers the above results to be chaotic with no easily discernible trend although a qualitative assessment shows little change in $\mathrm{CO}_{2}$ emissions an increase in $\mathrm{NOx}$ and $\mathrm{CO}$ emissions counterbalanced by an overall decrease in THC emissions.

The US Environmental Protection Agency [6] has surveyed biodiesel emissions studies and determined that $\mathrm{CO}$ emissions are, on average $48 \%$ lower than those from diesel and that THC emissions are reduced by $67 \%$. This study does not always confirm the above and it is considered that results need to be normalised to fuel energy content to obtain a meaningful comparison.

There is also the problem regarding sourcing of alternative fuels with the Renewable Energy Directive (RED) [3] requiring that biofuels meet sustainability criteria. There have also been reports of food growing land used for more profitable biofuel production. Other studies have examined the use of novel fuels, e.g. eucalyptus biodiesel and report considerable reduction in exhaust emissions using a non-edible fuel.

The advantages gained from using biodiesel fuels depend on a worldwide sustainable biodiesel capability and should be considered alongside methodologies for the improvement of power quality and the corresponding reduction in both emissions and the use of hydrocarbon fuels.

\subsection{Power Quality \\ 5.2.1 Engine development}

Power quality is indicated by the increase in engine efficiency and the reduction in $\mathrm{CO}_{2}$ and harmful emissions. Both are the subject of considerable research in both industry and academe. Topics under consideration include the reduction in friction [7], split injection [8], exhaust gas recirculation [9] and emissions after treatment [10].

\subsubsection{Alternative power sources}

Other developments examine alternatives to the ic engine and feature electric or hybrid vehicles.. Both depend on the availability of a 'clean' and plentiful supply of electricity since, although electric vehicles produce no emissions, power generation is usually anything but clean. There is also the range problem which makes electric vehicles very much an urban phenomenon, coupled with the scarcity of recharging outlets.

Clean nuclear energy is the only realistic energy source which would overcome these disadvantages [11] but is often the subject of anti-scientific opposition. Thus, electric vehicle propulsion in France, with $75 \%$ of its electricity generated from nuclear power with another $20 \%$ mostly hydroelectric, making their electrical production virtually gas and pollution free [11] makes the electric vehicle a clean alternative.

One mechanism for reducing the pollution problem and overcoming the range problem is the extended range electric vehicle [12]. Here, an auxiliary energy supply, typically an ic engine operating continually at its design optimum drives a generator in a battery electrical vehicle. The electric motor will give a vehicle the power and flexibility required for all operating conditions, enabling excellent acceleration and maximum speed which allows a much smaller ic engine to be employed than a conventional powertrain would need for the same performance specification.

In conclusion, exhaust emissions would be significantly reduced by a combination of engine development and alternative drive systems such as extended range vehicles, thus reducing the requirement for hydrocarbon fuels.

\section{References}

[1] $\mathrm{CO}_{2}$ Emission regulations: http://eur-lexeuropa.eu

[2] Euro Emissions standards: http://www.dieselnet.com/standards/eu

[3] Renewable Transport Fuels Obligation amendment: http://www.renewablefuelsagency.gov.uk

[4] KannenD, NabiMN \& HustadJE, 'Investigation of fuel properties and characterisation of new generation fuels for diesel engines', Paper 684/001, IMechE Conf on Internal Combustion Engines: Performance, Economy and Emissions, London, December 09.

[5] PlintMA \&MartyrAJ, 'Engine Testing: Theory and Practice' Butterworth-Heineman, 2007.

[6] US Environmental Protection Agency report www.epa.gov/otag/models/analysis/biodsl/p02001.pdf

[7] HerapathC, BarransSM \& WestonW, 'A Comparison of Design Methodologies for Journal Bearings under Pulsatile Loads', Paper 286, $11^{\text {th }}$ Int Conf on Renewable Energy and Power Quality, Las Palmas, April 2011.

[8] HerfatmaneshMR, ZhaoH \&GanippaL, 'In cylinder studies of split injection in a single cylinder diesel engine', Paper1328/008,:IMechE Conf, Internal Combustion Engines: Performance, Economy \& Emissions, London, December 2011.

[9] AtslerF, WeigandA KastnerO and RotondiR, 'Measures to improve the $\mathrm{NO}_{\mathrm{x}}-\mathrm{PM}$ trade off for passenger car diesel engines at elevatedengine load, Paper 684/040: IMechE Conf, Internal Combustion Engines, London,December 2009.

[10] HemmingsS, MegaritisT\& ZhaoH, 'Periodically regenerating particulate diesel filter with an $\mathrm{H}_{2} / \mathrm{CO}$ mixture addition', Paper C1328/001: IMechE Engine Conf, London, Dec 2011.

[11] Ian Hore-Lacy, " Nuclear Engineering in the $21^{\text {st }}$ Century', Elselvier Inc, 2006

[12] BassetMD, HallJ, DarkesD, FraserNAJ \& WarthM, 'Design of a dedicated range extender engine, Paper1328/012: IMechE Engine Conf, London, December2011. 